\title{
Evaluation of the Granulopoiesis during Antiblastic Treatment*
}

\author{
A. Fieschi, G. Sacchetti
}

The antiblastic treatment is commonly controlled through the granulocyte count which is often inadequate to assure a satisfactory information about the efficiency of the granulopoiesis. It is known indeed, that subjects with normal granulocyte count at the time the treatment is instituted, may develop granulocytopenia more rapidly than usual.

This question has been explained by the granulocyte kinetic studies which demonstrated a peculiar functional composition of the bone marrow granulocyte population which can be summarized as follows: r) a proliferative compartment in which myelocytes predominate; 2) a maturative compartment mainly due to metamyelocytes; 3) a "reserve" compartment due to nonsegmented and to mature granulocytes which provide a readily available supply of cells to be released into the peripheral blood upon demand.

The reserve compartment is a particular entity of the granulopoiesis large about 20 times the mass of the granulocytes in the blood (Craddock, I957; Sacchetti, I963).

In steady state condition the granulocyte reserve of the bone marrow is replaced about every 6 days: during this time, it releases mature cells at a rate sufficient to maintain the normal granulocyte count in the blood even if the granuloblasts proliferation in the marrow is stopped.

The disponibility of the bone marrow reserve of granulocytes appears of great interest for the evaluation of the granulopoiesis as well as for the control of the antiblastic treatment because the granulocytes survive in the blood with a $t / 2$ of about 7 hours, with a turnover rate of $95.25 \times 10^{9}$ cells for 24 hours. Moreover, it was demonstrated that granulocytes do not recirculate and that there is no extravascular or intratissutal store of granulocytes (Sacchetti, 1963; Boggs et al., 1964). The bone marrow reserve and the maturative pool consist of $1196 \times 10^{9}$ cells, one half of which are mature granulocytes (Ponassi et al., 1964; Sacchetti et al., 1965).

By means of chemotherapeutic agents or irradiation, the development of the granulocytic hypoplasia and the successive recovery have been studied in animals and confirmed in humans. The damage develops in the following phases: I) decrease

* Researches supported by C.N.R. (National Research Council); grant no. 2252/65 for ig62 and no. $04 / 79 / 4 / 3719$ for 1964 . 
or arrest of the proliferation; 2) progressive depletion of the marrow granulocyte reserve; 3) granulocytopenia in the blood. When recovery is possible, firstly increases the number of the granuloblasts in the bone marrow, then begins to rise the number of blood granulocytes. The latest event is represented by the rebuilding of the marrow granulocyte reserve (Fieschi and Sacchetti, I959; I964). In such a way, the blood granulocyte count may be normal also when the marrow reserve is markedly reduced and the antiblastic treatment may be followed by an unpredicted granulocytopenia.

The present study has been planned to control the damage and the recovery of the bone marrow granulocyte reserve in subjects treated with antiblastics: cyclophosphamide and nitrogen mustrard. The effect of the steroid on the recovery, during the induced granulocytopenia, has been studied too.

\section{Methods and materials}

The morphologic examination of the bone marrow does not offer any information about the reserve; therefore, other tests must be used: I) the quantitation of the bone marrow granulocyte reserve by means of in vivo labeling with $\mathrm{DFP}^{32}$; 2) mobilization of the bone marrow granulocyte reserve by means of endotoxin administered intravenously.

Administering the DFP32 intravenously in normal subjects and measuring the specific activity of blood granulocytes, the poliphasic curve, reported in Fig. I (on the left), is obtained. The first exponential phase represents the renewal of the blood granulocytes. The second flat portion is due to cells of the reserve and of the maturative bone marrow compartments. The duration of the phase I plus II represents the time required for a myelocyte to divide, mature and enter the blood as a segmented neutrophil. The administration of agents damaging the mitotic activity reduce the duration of the second flat curve because the mature cells continue to move into the blood and are not replaced by cells from the mitotic pool (Athens et al., I959; Fieschi and Sacchetti, I96r; I964). Being known the blood volume, the blood granulocyte mass and the granulocyte turnover rate in the blood, we can measure the size of the postmitotic pool (Sacchetti et al., r965). The third phase appears as an exponential function, however this curve is influenced by several factors but primarily reflects the myelocyte proliferating pool. The $t / 2$ of the $3^{\text {rd }}$ phase is reduced by antiblastics and increases when the mitotic pool is regenerating (Boggs et al., 1965).

The in vivo labeling with $\mathrm{DFP}^{32}$ (diisopropylfluorophosphate-P32 from the Radiochemical Center of Amersham, England) has been performed using the methods previously published (Athens et al., I959; Sacchetti et al., I96o; I963; Fieschi and Sacchetti, I96I; Morra et al., I 964).

Directs and indirects methods demonstrated that the injection of bacterial endotoxins is followed by a granulocytosis in the blood due to granulocytes mobilized from the bone marrow reserve. The degree of this granulocytosis is roughly propor- 

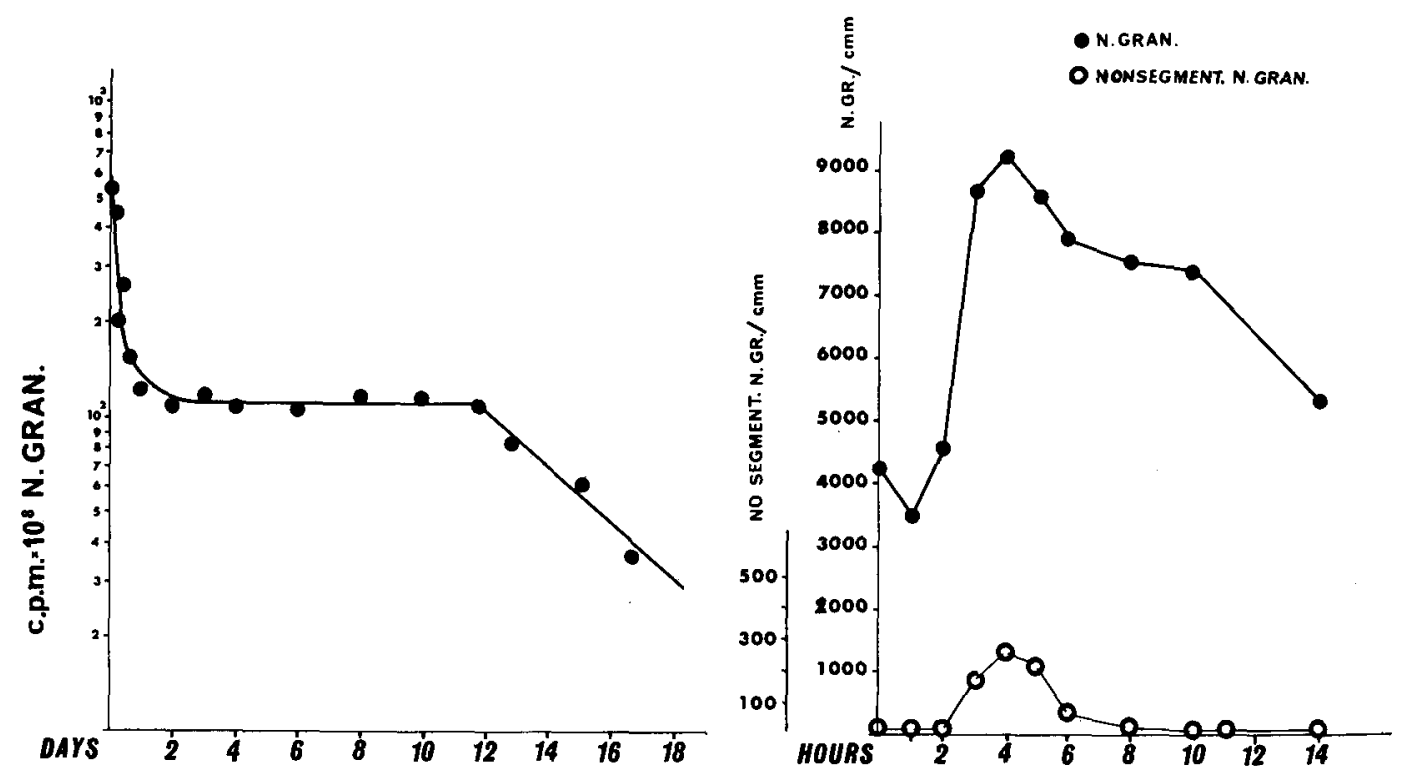

Fig. I

tional to the disponibility of the reserve (Craddock, 1957; Fieschi and Sacchetti, 196r; Sacchetti, I963; Ponassi et al., 1964; Sacchetti et al., 1964; Fieschi and Sacchetti, I959; I964; Sacchetti et al., I964). Combined endotoxin and DFP'32 studies indicated that the cells of the postmitotic pool move in a first in, first out manner: consequently, the nonsegmented granulocytes increases in the blood when the marrow reserve is reduced in size. An example of the DFP32 and of the endotoxin test performed in the same normal subject is reported in Fig. $\mathrm{I}$ : the DFP ${ }^{32}$ curve shows a flat portion of normal duration; the endotoxin test with (the curve on the right) o.I gamma of Pyrexal (purified lipopolysaccharides from the salmonella abortus aequi, produced by dr. Wander, Basel) shows a maximal granulocytosis at the $4^{\text {th }}$ hour without a significative increase of nonsegmented granulocytes. In our laboratory the marrow granulocyte reserve is considered of "normal size" if the endotoxin test evokes a granulocyte maximal count of at least 3 ooo cells per $\mathrm{cmm}$ above the base line without "left shift". The marrow reserve is considered to be "reduced in size", if the granulocyte count fails to increase or does not reach the 3 ooo cells per $\mathrm{cmm}$ in respect to the base line with "left shift" (band cells over $4^{\text {oo }}$ per $\mathrm{cmm}$ ). During the present studies, the endotoxin test was performed 2 days before every administration of $\mathrm{DFP}^{32}$. It was done because previous researches demonstrated that the test is without consequence on the duration of the phases of the DFP32 curve (Ponassi et al., I964). Details on the endotoxin test have been reported in other papers (Sacchetti, r963; Ponassi et al., r964; Sacchetti et al., r964; 1965).

Combined $\mathrm{DFP}^{32}$ and endotoxin studies have been executed in over 80 cases of 
various diseases requiring chemotherapy or irradiation, however, in this occasion we refer to two groups of 5 subjects with Hodgkin disease not previously treated, in which both the DFP ${ }^{32}$ and the endotoxin studies bave been performed in 3 successive occasions: before the therapy, soon after the antiblastic therapy was discontinued and after a $3^{\circ}$ days interval. These groups have been chosen because of the complete normality of the hematological data, the absence of blood loss and the absence of complications during the whole period of study. Cyclophosphamide (Endoxan, Zillichen) and methyl-bis (betacloroethyl-amine hydrochloride (Cloramin, Simes) has been used respectively in the dose of $7 \mathrm{gr}$ and $5^{\circ} \mathrm{mg}$ during 20 days.

Prednison is often administered during the interval between successive cycles of antiblastics. Is is known that prednison induces granulocytosis and it was considered able to stimulate granulopoiesis. The mechanism of the granulocytosis induced by prednison bas been studied using granulocytes labeled in vivo and in vitro with DFP32. The labeling in vitro is performed adding the isotope to the whole blood collected in plastic bags and returning the labeled cells to the donor (Fieschi and Sacchetti, Ig6r; Boggs et al., I964). One subject treated with nitrogen mustard at the same dose and duration as previously indicated, has been studied in three occasions: at the end of the antiblastic treatment; after 6 days with $60 \mathrm{mg} / \mathrm{d}$ of prednison and 4 days after prednison was discontinued. As a control, the values of previous studies in normal subjects treated for $\mathrm{I}_{5}$ days with $30 \mathrm{mg} / \mathrm{d}$ of prednison have been used (Sacchetti et al., I962).

\section{Results}

\section{A - Subjects treated with antiblastics}

I - DFP $P^{32}$ in vivo studies.

The results in cyclophosphamide and in the nitrogen mustard treated subjects are reported in Tab. 2. The starting values are comparable with those obtained from 40 normal subjects (Morra et al., I964) and reported in Tab. I. An example of the successive DFP32 studies performed in the same subject is reported in Fig. 2. The first curve has been obtained before the treatment and it shows phases of normal duration; the second one, starting two days after the nitrogen mustard was discontinued, shows a flat portion of short duration ranged between 4 and 7 days in contrast with the normal mean value of 12 days. The curve obtained after a 30 days interval shows normal values: however in about $\mathrm{I} / 2$ of all the studied cases, the second phase of the curve appears not fully normalized.

2 - Disponibility of the bone marrow granulocyte reserve: endotoxin test.

The responses to the endotoxin test are reported in Tab. 3. The normal values (normal subjects controlled with the in vivo labeling with $\mathrm{DFP}^{32}$ ) are reported in Tab. I. 
Acta Geneticae Medicae et Gemellologiae

Tab. 1. Normal subjects: values on 40 cases

\begin{tabular}{|c|c|c|c|c|c|c|c|c|}
\hline & \multicolumn{5}{|c|}{$\mathrm{DFP}^{32}$} & \multicolumn{3}{|c|}{ Reserve mobilization test } \\
\hline & TBGM & GTR & $\mathrm{T} 1 / 2$ & $\mathrm{PD}$ & MGR & $\mathrm{NG} / \mathrm{BL}$ & $\mathrm{NG} / \mathrm{Mx}$ & BCII \\
\hline Mean & 40.15 & $94 \cdot 53$ & 7h $2^{\prime}$ & I $2 \mathrm{~d}$ I $6 \mathrm{~h}$ & I I 70.6 I & $373^{\circ}$ & $84^{87}$ & 4.06 \\
\hline Min. & 27.19 & $82.5^{\circ}$ & $5^{\text {h }} 4^{\prime}$ & Iod $3^{\mathrm{h}}$ & $835 \cdot 5^{\circ}$ & 3100 & 7050 & I. 15 \\
\hline Max. & 53.12 & I I 4.27 & $8 \mathrm{hr} 5^{\prime}$ & I $4 \mathrm{~d} 4 \mathrm{~h}$ & I $476.3^{8}$ & 4800 & I 0800 & 7.00 \\
\hline
\end{tabular}

I. Granulocyte kinetics with $\mathrm{DFP}^{32}$ « in vivo »: TBGM $=$ total blood granulocyte mass $\times 10^{9} ; \mathrm{GTR}=$ granulocyte turnover rate $\times 10^{9}$ per 24 hours; $\mathrm{T} 1 / 2=$ half-time disappearance of the granulocytes from the blood; $\mathrm{PD}=$ plateau duration; $\mathrm{MGR}=$ size of the marrow granulocyte reserve $\times 10^{9}$.

2. Reserve mobilization test with endotoxin: NG/BL $=$ neutrophilic granulocyte base line count per $\mathrm{cmm}$ before Pyrexal; $\mathrm{NG} / \mathrm{Mx}=$ neutrophilic granulocytes, maximum value per $\mathrm{cmm}$ after Pyrexal; $\mathrm{BCII}=$ band cells increase index (band cells per cent increase of the total maximal granulocytes increase.

Tab. 2. Granulocyte kinetics studied with DFP32 administered in vivo

\begin{tabular}{|c|c|c|c|c|c|c|c|c|c|c|c|c|c|}
\hline \multicolumn{5}{|c|}{$\mathrm{A}$} & \multicolumn{4}{|c|}{$\mathbf{B}$} & \multicolumn{5}{|c|}{$\mathrm{C}$} \\
\hline TBGM & GTR & $\mathrm{T} 1 / 2$ & $\mathrm{PD}$ & MGR & TBGM GTR & $\mathrm{T} 1 / 2$ & PD & MGR & TBGM & GTR & $\mathrm{T} 1 / \underline{1}$ & $\mathrm{PD}$ & MGR \\
\hline
\end{tabular}

Cyclophosphamide treated subjerts

\begin{tabular}{|c|c|c|c|c|c|c|c|c|c|c|c|c|}
\hline 41.23 & 93.68 thr9' & d23h & $88_{4}$ & 7.89 & 6.24 & $5^{h}$ & . & 3 & & 88.02 & & 960 \\
\hline 70.09 & I 59.6 I 7 hI $8^{\prime}$ & I Id & I 685 & $3 \cdot 70$ & $5 \cdot 57$ & $5^{\text {hIC }}$ & $7 \mathrm{~d}$ & 305 & $44 \cdot 31$ & II $3.166 \mathrm{~h}_{30} \mathrm{o}^{\prime}$ & $12 \mathrm{~d}$ & \\
\hline I 5 & I02.1 $88 \mathrm{hr}$ & $13 \mathrm{~d}$ & 277 & 8.29 & 7 & $6 h$ & $5 \mathrm{~d} 2$ & & $7 \mathrm{I}$ & & d & \\
\hline 43.1 & $89 \cdot 7^{6}$ & $3 \mathrm{digh}$ & 21 & $7 \cdot 5^{\circ}$ & 4.94 & & & & $3^{6.5^{\circ}}$ & & & \\
\hline 10.7 & $9^{8.35} 6 \mathrm{~h}_{53^{\prime}}$ & 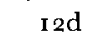 & 120 & 2 & 4.03 & 5 h25 & $5^{\circ}$ & 59 & 42.28 & 0.56 & $7 \mathrm{~d} 16 \mathrm{~h}$ & \\
\hline
\end{tabular}

Nitrogen mustard treated subjects

\begin{tabular}{|c|c|c|c|c|c|c|c|c|c|c|c|}
\hline 49.23 & $5.4^{\circ}$ & $7^{h_{4}} 3^{\prime}$ & 100 & 004 & I $3 \cdot 7^{6}$ & & $7 \mathrm{hI}_{4}^{\prime}$ & & & & \\
\hline 40.79 & 90.28 & $7 h_{3}$ & I Id & 997 & 6.35 & 8 & $5^{h}$ & & & 50 & \\
\hline 37.12 & 102.69 & $6 h$ & & I & 9.06 & 5 & Sho & 6 & & & \\
\hline 54 & 12.42 & & $\operatorname{rod} 6 \mathrm{~h}$ & $\operatorname{Iog} 8$ & 0.4 & 28.77 & & 7 & .25 & & \\
\hline 61.24 & 19. & & h & 1404 & no & $17.3^{6}$ & $135^{\prime} 6 \mathrm{~d} 8 \mathrm{~h}$ & 02 & 5.61 & 54.85 & \\
\hline
\end{tabular}

Subjects treated with cyclophosphamide and nitrogen mustard and controlled: A) before treatment; B) after treatment; C) 30 days after the treatment was discontinued.

Abbreviations as in Tab. $\mathbf{I}$.

Fig. 3 reports the endotoxin test performed in the same subject (the same of Fig. 2) and in the same occasions above indicated for the labeling studies. Before treatment, the granulocyte response appears of normal degree without "left shift". After treatment the granulocytosis fails to develop and a significative " left shift" appears, due to the increase of nonsegmented granulocytes as indicated by the bar at the bottom. After a 30 days interval, the response attains values within the normal range suggesting the recovery of the reserve. 


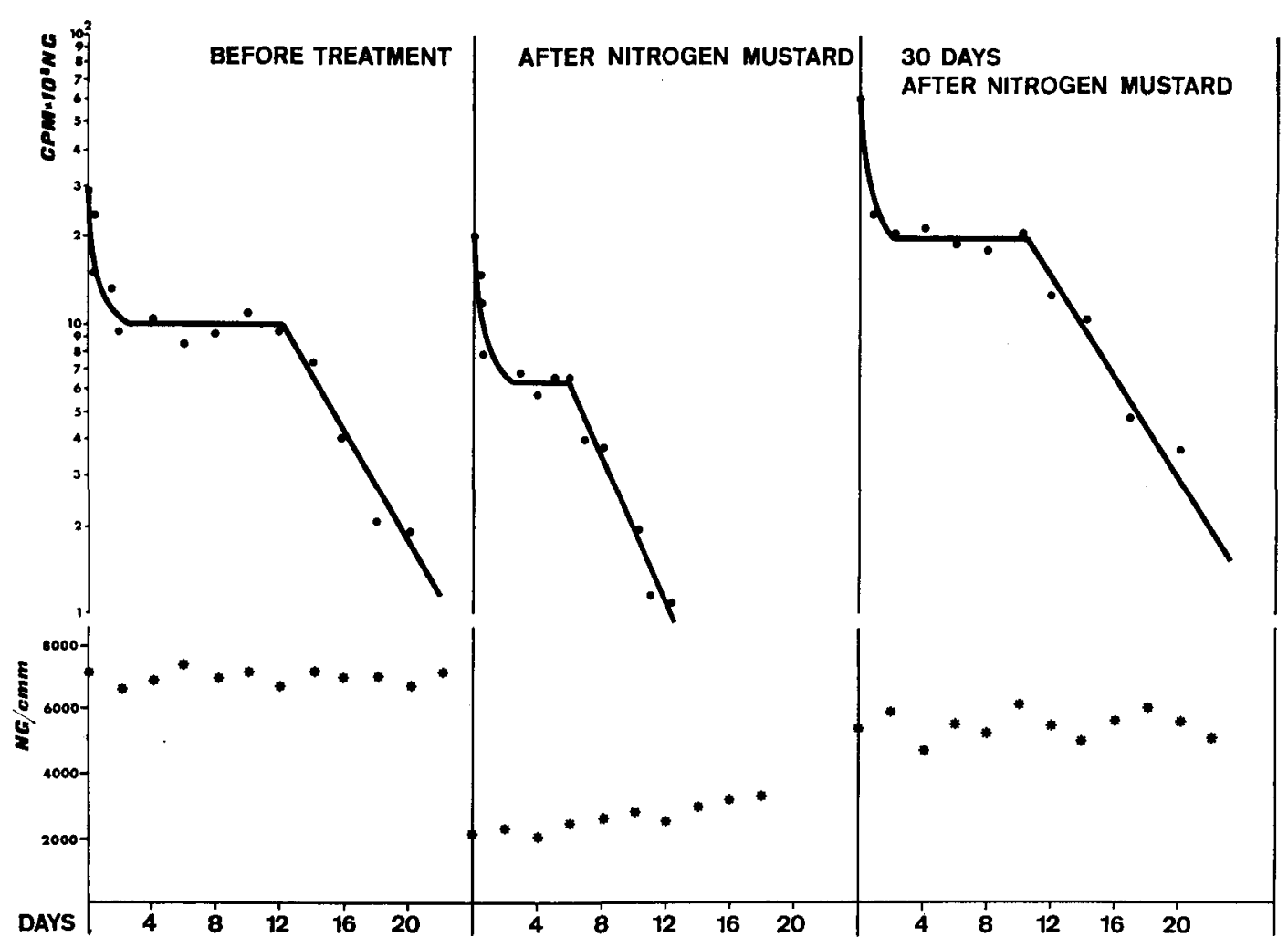

Fig. 2

Tab. 3. Evaluation of the bone marrow granulocyte reserve by means of the " reserve mobilization test"

\begin{tabular}{|c|c|c|c|c|c|c|c|c|c|}
\hline & & $\mathrm{A}$ & & & B & & & $\mathrm{C}$ & \\
\hline & NG/BL & $\mathrm{NG} / \mathrm{Mx}$ & BCII & NG/BL & $\mathrm{NG} / \mathrm{Mx}$ & BCII & $\mathbf{N G} / \mathbf{B L}$ & $\mathrm{NG} / \mathrm{BL}$ & BCII \\
\hline Cyclop & sphamide tr & ed subjects & & & & & & & \\
\hline I & 4000 & 8300 & 4. 18 & 900 & I 300 & 32.2 & $3^{800}$ & 7200 & 6.40 \\
\hline 2 & $95^{\circ 0}$ & 14700 & $8.4^{8}$ & 1200 & 2000 & I 6.5 & 4200 & 9100 & $3 \cdot 74$ \\
\hline 3 & 5900 & 12300 & 2.92 & I 100 & 1800 & $23 \cdot 5$ & 3500 & 4900 & I5.39 \\
\hline 4 & 4200 & 10300 & 2.00 & 900 & I 700 & 25.2 & 4300 & $6 g \circ o$ & 22.44 \\
\hline 5 & 4100 & 9700 & $4 \cdot 4^{6}$ & IOOO & 1800 & 28.7 & 3300 & 4400 & $3^{1.71}$ \\
\hline Nitrog & mustard tr & ted subjects & & & & & & & \\
\hline I & $3^{800}$ & 8900 & 5.12 & I IOO & I 700 & $35 \cdot 3$ & 3400 & 7200 & $4 \cdot 74$ \\
\hline 2 & 4600 & IOIOO & 3.08 & 900 & 1500 & 40.6 & 4 IOO & 9000 & $6.2 \mathrm{I}$ \\
\hline 3 & $35^{00}$ & 9000 & 6.45 & 1200 & 2000 & I9.3 & 3900 & $5^{100}$ & I 5.77 \\
\hline 4 & 6900 & I 5300 & 7.21 & 1800 & 2800 & $4^{8.8}$ & 4800 & I 0400 & 6.80 \\
\hline 5 & $5^{200}$ & I 4900 & $3 \cdot 78$ & 800 & I 400 & 28.4 & 4500 & 5900 & 22.35 \\
\hline
\end{tabular}

Subjects treated with cyclophosphamide and nitrogen mustard and controlled: A) before treatment; B) after treatment; C) 30 days after the treatment was discontinued.

Abbreviations as in Tab. I. 
Acta Geneticae Medicae et Gemellologiae
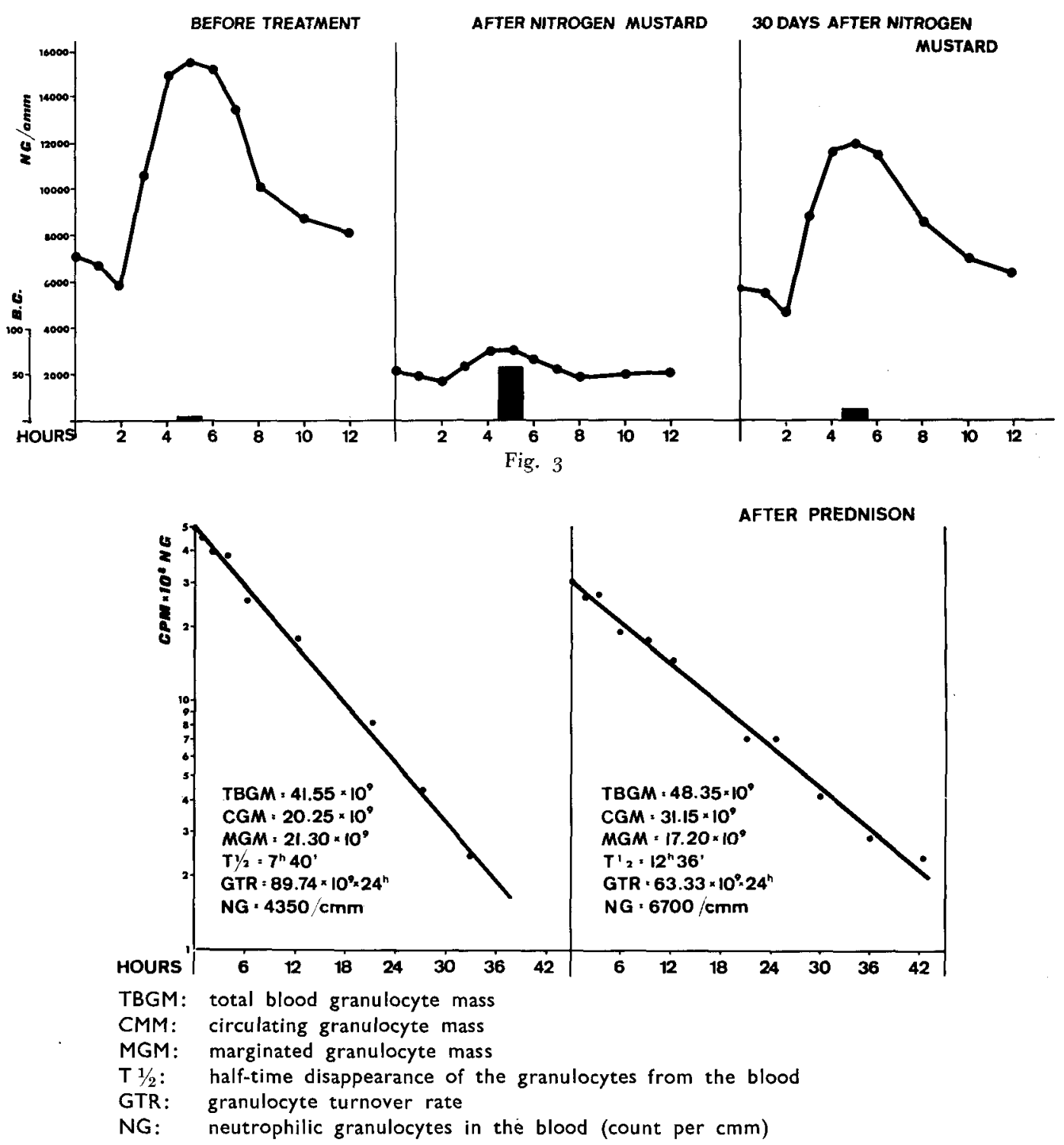

Fig. 4

\section{B - Steroid treatment duRing GRANUloGytopenia}

The effect of prednison on the recovery of the total blood granulocyte mass (TBGM) has been studied with autotransfusions of in vitro labeled granulocytes. Fig. 4 shows the result of the autotransfusion of labeled granulocytes in a normal 


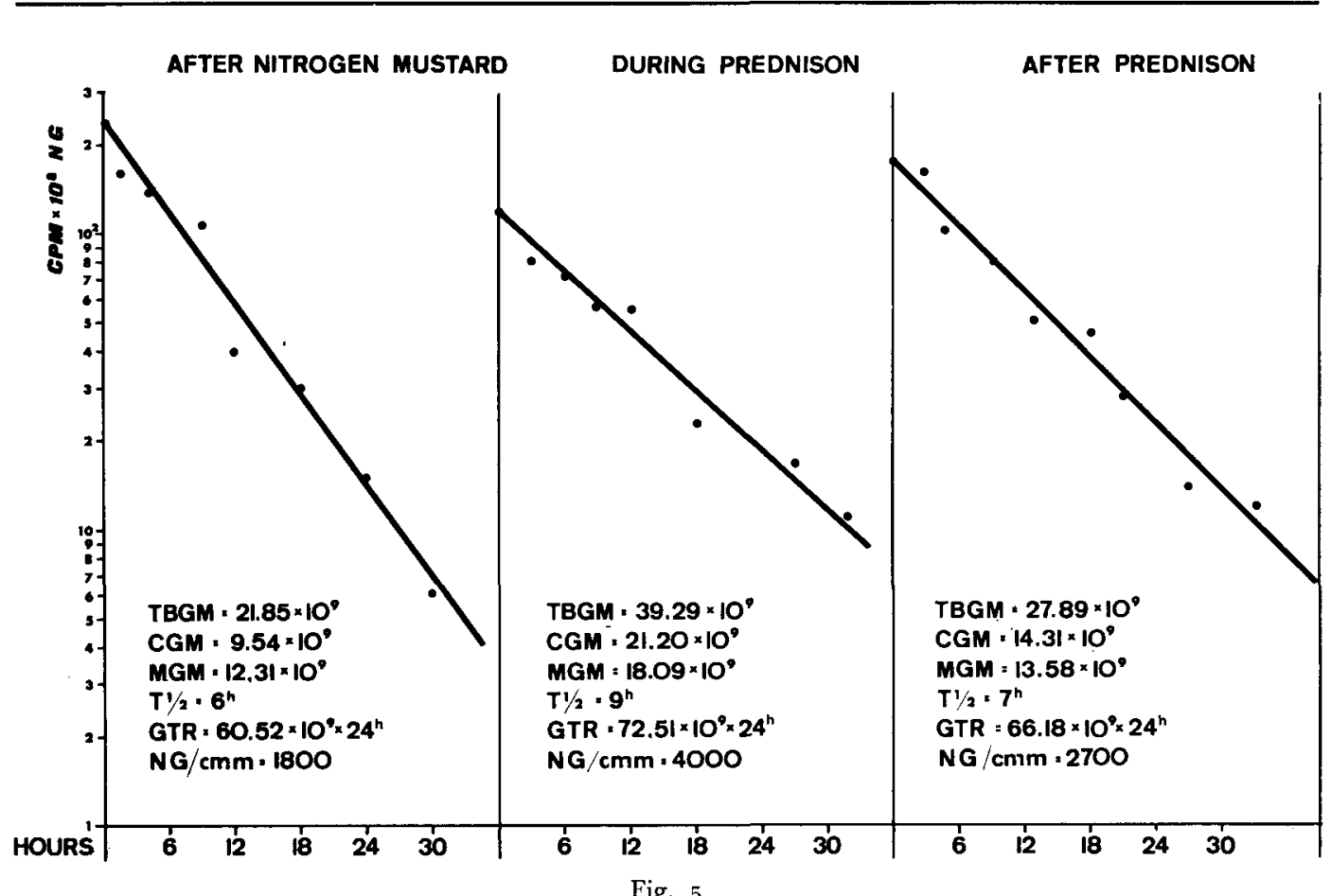

subject. This curve corresponds to the first exponential phase of the curve obtained using DFP' in vivo. The other curve has been obtained in the same subject after I5 days with $30 \mathrm{mg}$ a day of prednison. With prednison the granulocyte count and the TBGM increases but also the $t / 2$ of survival in the blood increases and the granulocyte turnover rate (GTR) decreases. In this condition the in vivo labeling does not show any modification of the whole curve. These facts suggest that the prednison does not stimulate the granulopoiesis but induces a granulocytosis reducing the utilization of the granulocytes.

Autotransfusion experiments have been performed in one subject with granulocytopenia due to nitrogen mustard: Fig. 5. The first control shows a TBGM reduced confirming the granulocytopenia. The second control, performed after 6 days of prednison, shows an increase of the granulocyte count, a significative increase of the TBGM and a $t / 2$ of longer duration. The third control, 4 days after prednison was discontinued, shows a reduction of the TBGM and a normalization of the granulocyte $t / 2$ in the blood.

\section{Discussion}

When the "normality" of the granulopoiesis and the possibility of a new cycle of antiblastic treatment are to be judged in presence of normal granulocyte counts, the circulating granulocytes count alone is often inadequate to assess the efficiency 
of the granulopoiesis. A normal TBGM has been in fact observed, labeling granulocytes with $\mathrm{DFP}^{32}$ in vitro, even in presence of a reduced bone marrow reserve (Sacchetti, I963; Fieschi and Sacchetti, 1964). This finding is frequent after radiation or antiblastic treatment and make it necessary to control the degree of the recovery.

Steroid treatment is well known to induce neutrophilic leukocytosis, and it is often used to hasten the recovery of the granulopoiesis. However, researches done by us (Fieschi and Sacchetti, I96I; Sacchetti et al., 1962) and by others (Mauer et al., I960; Athens et al., 1962) agree in excluding that the steroid treatment increases the bone marrow production of granulocytes.

The present studies were done in subjects having to undergo antiblastic treatment and controlled to be in steady state conditions before the therapy. Two antiblastic drugs, known to induce granulocytopenia but having different degree of toxicity, have been chosen. Particular accuracy has been devoted to evaluating the availability of the bone marrow reserve studied with the bacterial endotoxin test and with the granulocyte labeling in vivo with $\mathrm{DFP}^{32}$.

The results obtained after $\mathrm{DFP}^{32}$ in vivo, at the end of the antiblastic treatment, showed the granulocytopenia to be joined with a shortening of the second phase of the curve, corresponding to the mature granulocytes of the reserve and to the granulocytic cells of the maturative compartment of the bone marrow. Disappearance of the flat portion of the curve has been never observed, even in subjects with very low granulocyte counts: 4 days and ig hours being the shortest duration observed in the present study, corresponding to I I $7 \times 10^{9}$ cells (mean normal value: $\mathrm{I} 2 \mathrm{~d}$ and $\mathrm{I} 6 \mathrm{~h}$ with I $\mathrm{I} 70 \times \mathrm{IO}^{9}$ cells). In these conditions the mobilization of mature granulocytes, with Pyrexal, is not followed by granulocyte increase in the blood: the bone marrow reserve is supposed to be actually depleted as a result of an inadequate supply of cells from the proliferating compartment. This interpretation is supported by the shortening of the $\mathrm{t} / 2$ of the $3^{\text {rd }}$ phase of the curve with DFP ${ }^{32}$ (observed in two occasions at the end of the antiblastic treatment) suggesting the impairment of the proliferating myelocyte pool. Recently, similar results and interpretations have been reached by Boggs and others in dogs treated with vinblastine (1965). In occasional survey of subjects in which the labeling has been started at different times after the beginning of the antiblastic therapy, we never observed abrupt drop of the bone marrow reserve. These observations (which need further confirmation) would indicate that the depletion of the reserve and the granuloblastic hypoplasia are due mainly to the compromission of the proliferating pool rather than to cellular lysis.

The $\mathrm{DFP}^{32}$ in vivo studies performed after a $3^{0}$ days interval show a flat portion of the curve not completely normalized in one half of all the cases. This value seems unrelated to particular events in the course of the disease and appears to indicate that the rebuilding of a bone marrow reserve of normal size takes place slowly, without a definite relationship with the granulocyte concentration in the blood because the granulocyte counts in the blood appear within the normal range about I4 days after the end of the treatment. Controls, carried out 30 days after the treatment was discontinued, did not show significative differences about the conditions of the re- 
covery of the bone marrow reserve between the subjects treated with cyclophosphamide or with nitrogen mustard.

The results obtained in the subject treated with Prednison and controlled with repeated autotransfusions of granulocytes labeled with DFP $^{32}$, after the nitrogen mustard was discontinued (Fig. 5), showed only temporary increase of the TBGM and of the $t / 2$ of granulocyte survival in the blood. These results suggest that the mechanism of the recovery of the granulopoiesis during Prednison does not concern the bone marrow but only the peripheral utilization of the blood granulocytes (Athens et al., I962; Sacchetti et al., I962; Sacchetti, I963; Fieschi and Sacchetti, I964): therefore, the granulocyte count cannot be considered as a satisfactory tool of information but it must be completed by exploring the reserve disponibility.

\section{Summary}

Selected subjects have been treated with cyclophosphamide and nitrogen mustard. The granulocytopenia has been followed by repeated in vivo labeling with $\mathrm{DFP}^{\mathbf{3 2}}$ and the endotoxin test for evaluating the availability of the granulocyte reserve. The effect of steroid treatment on the recovery of the granulopoiesis has been studied with autotransfusions of in vitro $\mathrm{DFP}^{32}$ labeled granulocytes in the same subject and performed before, during and after the treatment was discontinued.

The following conclusions have been reached:

I. The efficiency of the granulopoiesis is based upon the availability of the bone marrow granulocyte reserve.

2. The bone marrow granulocyte mobilization with endotoxin and the in vivo granulocyte labeling with $\mathrm{DFP}^{32}$ give an evaluable information about the bone marrow granulocyte reserve.

3. The granulocytopenia due to antiblastic therapy corresponds to a depletion of the bone marrow granulocyte reserve.

4. The recovery of a "normal granulocyte count" preceeds the rebuilt of a " normal availability" of the bone marrow granulocyte reserve.

5. The recovery of the blood granulocyte count after prednison is not associated with any favourable change of the granulopoiesis.

\section{References}

Athens J. W. et al. (1959). Leukokinetic studies. I -A method for labeling leukocytes with diisopropylfluorophosphate (DFP's2). Blood, 14: 303 .

- et al. (1962). The mechanism of steroid granulocytosis. F. Clin. Invest, 41: 1342.

Boggs D. R. et al. (1964). Leukokinetic studies. VIII-A search for an extramedullary tissue pool of neutrophilic granulocytes. Proc. Soc. Exptl. Biol. Med., 115: 792.

- et al. (I965). Leukokinetic studies. IX - Experimental evaluation of a model granulopoiesis. 7. Clin. Invest., 44: 643 .

Craddock G. G. Jr. (1957). Newer concepts of leukopoiesis as revealed by leucophoretic and isotopic techniques. H. Ford. Hosp. Int. Symp., Acad. Press. N. Y., 245. 
Fieschi A., (Ig6I). Dinamica dei Granulociti: Leucocitosi e Leucopenie. Ed. L. Pozzi, Roma.

- Sachetre C. (1959). Dynamic behaviour of bone marrow granuloblasts in leukopenia and leukocytis. Acta Haemat., 22: 79 .

- (I964). Clinical assessment of granulopoiesis. Acta Haematol., 31: 150.

Maver A. M. et al. (1960). Leukokinetic studies. II-A method for labeling granulocytes «in vitro" with radioactive diisopropylfuorophosphate $\left(\mathrm{DFP}^{32}\right)$. 7. Clin. Invest., 39: $14^{8}$ I.

Morra L. et al. (1964). Dinamica dei granulociti nel sangue. Osservazioni comparative mediante marcatura « in vivo» dei granulociti ed autotrasfusione di granulociti marcati « in vitro ». Riv. Emoter. Immtnoematol., 11: IOI.

Ponassi A. et al. (1964). Studio della leucocitosi prodotta dalla somministrazione endovena di endotossine batteriche nell'uomo: provenienza, distribuzione e durata nel sangue dei granulociti mobilizzati. Minerza Nucleare, 8: 333 .

SAcChetтi G. et al. (i 960 ). Impiego del diisopropilfluorofosfato-P ${ }^{32}$ per lo studio della massa leucocitaria e della sopravvivenza dei leucociti. Atti XVII Congr. Naz. Soc. It. Ematol., Ed. EMES, Roma, 237.

- et al. (1962). J granulociti nel sangue: massa totale e compartimenti. Boll. Soc. It. Biol. Sper., $37:$ I 142.

- et al. (1962). Effetto del trattamento prednisonico sul rinnovamento dei granulociti nel sangue e sulla granulopoiesi in condizioni normali e patologiche. Folia Endocrin., 15: 730.

- (1963). La granulocitopoiesi: fisiopatologia e clinica. Ed. Cappelli, Bologna.

- et al. (1964). La riserva midollare di granulociti neutrofili. Minerva Nucleare, 8: 324 .

- et al. (I964). Osservazioni sulla dinamica dei granulociti nelle neutropenie. Riv. Emoter. Immunoematol., 9: 6o.

- et al. (1965). Evaluation of the granulocyte bone marrow reserve: its role on the prevention and control of radiation effects. Nuclear Energy Brithton Conf., 109.

一 et al. (1965). Neutrophilic leukocyte reserve of the bone marrow: « in vivo » detection and quantitation with DFP's. Minerva Nucleare, 9: 55 .

\section{RIASSUNTO}

Due gruppi di soggetti selezionati affetti da morbo di Hodgkin sono stati trattati con ciclofosfamide e mostarde azotate. La granulocitopenia è stata controllata con ripetute marcature in vivo dei granulociti con $\mathrm{DFP}^{32}$ e mediante il test con endotossine per valutare la disponibilità della riserva midollare.

L'effetto del trattamento steroideo sul recupero della granulopoiesi è stato studiato con autotrasfusioni di granulociti marcati in vitro con $\mathrm{DFP}^{32}$ eseguite nello stesso soggetto prima, durante e dopo che il trattamento è stato sospeso.

Si sono raggiunte le seguenti conclusioni:

1. L'efficienza della granulopoiesi è basata sulla disponibilità della riserva midollare di granulociti.
2. La mobilizzazione dei granulociti dal midollo osseo con endotossine e la marcatura in vivo dei granulociti con $\mathrm{DFP}^{32}$ danno informazioni attendibili sulla riserva midollare di granulociti.

3. La granulocitopenia dovuta a terapia antiblastica corrisponde alla deplezione della riserva midollare di granulociti.

4. Il recupero di un « conteggio granulocitario normale » precede la ricostruzione di una « normale disponibilità 》 della riserva midollare di granulociti.

5. Il recupero del conteggio granulocitario dopo prednisone non è associato a stimolazione della granulopoiesi midollare. 


\section{RESUMÉ}

On a traité des sujets sélectionnés avec cyclophosphamide et moutardes azotées. La granulocytopénie a été contrôlée par des administrations sériées de $\mathrm{DFP}^{32}$ in vivo et par le test avec endotoxine pour évaluer la disponibilité de la réserve granulocytaire.

L'effet de la thérapie prednisonique sur la normalisation de la granulopoï̀se a été étudié avec autotransfusion de granulocytes marqués in vitro par $\mathrm{DFP}^{32}$, effectuée dans le même sujet avant, pendant et après que la thérapie avait été terminée.

On a eu les conclusions suivantes:

1. L'efficacité de la granulopoìèse est basée sur la disponibilité de la réserve médullaire de granulocytes.
2. La mobilisation des granulocytes de la moelle osseuse par les endotoxines et le marquage in vitro des granulocytes donnent des données significatives sur la réserve médullaire des granulocytes.

3. La granulocytopénie due à la thérapie antiblastique est en rapport avec la déplétion de la réserve médullaire des granulocytes.

4. La normalisation quantitative des granulocytes circulants précède la reconstitution d'une disponibilité normale de la réserve médullaire des granulocytes.

5. La normalisation quantitative des granulocytes circulants après prednisone n'est associée à aucune modification favorable de la granulopoïèse.

\section{ZUSAMMENFASSUNG}

Ausgewählte Patienten wurden mit Cyclophosphamide und Nitrogen-Senfen behandelt. Die Granulozytopenie wurde durch Serien-Verabreichung von $\mathrm{DFP}^{32}$ in vivo und durch den Endo-toxine-Test kontrolliert, um des Niveau der Granulozytenreserve zu beurteilen.

Die durch die Prednisontherapie bewirkte Normalisierung der Granulopoëse wurde durch Autotransfusion von Granulozyten beobachtet, die ir vitro mit $\mathrm{DFP}^{32}$ markiert worden waren. Jeder Patient erhielt eine solche Autotransfusion vor Beginn, während und nach Beendigung der Therapie.

Man kam zu folgenden Ergebnissen:

1. Die Wirksamkeit der Granulopoëse hängt von dem Niveau der Knochenmarksreserve der Granulozyten $\mathrm{ab}$.

2. Die Mobilisierung der Knochenmarksgranulozyten mittels Endotoxine und die Markierung der Granulozyten in vitro liefern bedeutungsvolle Angaben über die Knochenmarksteserve der Granulozyten.

3. Die durch die antiblastische Therapie bedingte Granulozytopenie steht mit dem Absinken der Knochenmarksteserve der Granulozyten in Zusammenhang.

4. Die quantitative Normalisierung der im Kreislauf befindlichen Granulozyten erfolgt eher als die Wiederherstellung eines normalen Niveaus der Knochenmarksreserve der Granulozyten.

5. Die quantitative Normalisierung der im Kreislauf befindlichen Granulozyten nach Verabreichung von Prednison geht nicht mit irgendeiner günstigen Veränderung der Granulopoëse einher. 